\title{
Advanced Oncoplastic Breast Conserving Surgery: Single Institution Experience with 823 Patients
}

\author{
Andrii Zhygulin*, Artem Fedosov, Valentyn Palytsia, Daria Vinnytska, Vitalii Nedielchev, Mykhailo Uspenskyi, \\ Natalia Rybak
}

Breast Unit, LISOD Hospital of Israeli Oncology, Kyiv, Ukraine

*Corresponding author:

Andrii Zhygulin MD

Head of Breast Unit

LISOD Hospital of Israeli oncology

Malyshko str. 27, Pliuty vil.

Obukhiv distr. Kyiv region

08720, Ukraine

E-mail: zhygulin@lisod.ua
Received: 20.01.2021 Accepted: 17.03 .2021

\section{Rezumat}

Chirurgie oncoplastică avansată de conservare a sânului: experiența unui singur centru cu 823 de pacienți

Context: Chirurgia oncoplastică de conservare a sânului (BCS) devine standardul de îngrijire în tratamentul multidisciplinar al cancerului de sân. Din perspectiva noastră, scopul BCS oncoplastice este obținerea celor mai bune rezultate din punct de vedere oncologic, estetic şi funcțional. Obiectivele studiului prezent sunt de a prezenta abordările noastre privind selecția tehnicilor chirurgicale şi de a identifica rezultatele oncologice în chirurgia oncoplastică. Metode: Acest studiu este retrospectiv, unicentric şi include pacienții la care s-a practicat BCS pentru cancer de sân între 2007 şi decembrie 2020. Au fost analizate caracteristicile demografice şi clinicopatologice, precum şi complicațiile postoperatorii. Analiza a fost efectuată luând în considerare tipurile de proceduri efectuate. Intervențiile chirurgicale au fost clasificate în două tipuri: 1 . cu deplasarea volumului (nivel 1; deplasări avansate ale parenchimului; mamoplastii terapeutice) şi 2 . tehnici de înlocuire a volumului (lambouri regionale cu bază largă, lambouri perforante regionale insulare). Considerăm ca oncoplastice toate operațiile care sunt planificate şi efectuate având ca scop un rezultat estetic optim indiferent de tehnica utilizată.

Rezultate: Au fost efectuate 833 intervenții chirurgicale la 823 de pacienți cu cancer. În 153 de cazuri, au fost efectuate proceduri de simetrizare. Greutatea medie a pieselor de rezecție a fost de $112,9 \mathrm{~g}(2-1034 \mathrm{~g})$; dimensiunea medie a tumorilor a fost de $2,8 \mathrm{~cm}$ $(0,2-15,8 \mathrm{~cm}) .106$ pacienți $(12,7 \%)$ au avut tumori multifocale / multicentrice. În 32 de cazuri $(3,8 \%)$ au fost identificate margini de rezecție invadate tumoral şi a fost necesară reexcizia. $793(96,4 \%)$ 
pacienți au fost urmăriți postoperator pe termen lung. Perioada medie de urmărire a fost de 48 de luni (6-164 luni). Recurența locală a fost identificată la $10(1,2 \%)$ pacienți, recurența axilară regională - la $2(0,3 \%)$, progresia sistemică - la $87(11,0 \%)$ pacienți şi $50(6,2 \%)$ dintre ei au decedat. $\mathrm{Au}$ fost observate complicații la $190(23,1 \%)$ pacienți, reprezentate în principal de seroame şi tulburări ischemice.

Concluzii: Acest studiu prezintă abordările noastre pentru chirurgia oncoplastică de conservare a sânilor, concentrându-se pe rezultatele estetice ale procedurilor. Rezultatele oncologice demonstrează siguranța intervențiilor chirurgicale oncoplastice avansate în contextul gestionării pacientului într-o echipă multidisciplinară.

Cuvinte cheie: chirurgie mamară oncoplastică, mamoplastie terapeutică, lambouri perforante regionale, intervenție chirurgicală de conservare a sânilor, înlocuirea volumului, deplasarea volumului

\begin{abstract}
Background: Oncoplastic breast conserving surgery (BCS) becomes the standard of care in multidisciplinary breast cancer treatment. From our perspective, the aim of oncoplastic BCS is the best oncological, aesthetic and functional surgical treatment results. The study's objective is to present our approaches to the selection of surgical techniques and determine operative and oncological outcomes of oncoplastic surgery.

Methods: This retrospective study presents a single institution experience with patients who underwent oncoplastic BCS for breast cancer between 2007 and December 2020. Demographic and clinicopathologic characteristics as well as postoperative complications were analyzed. The analysis was performed by taking into account the types of procedures. Surgeries were categorized into two types: 1. volume displacement (level 1; advanced parenchyma displacements; therapeutic mammaplasties) and 2. volume replacement techniques (regional flaps with wide base, regional island perforant flaps). We consider as oncoplastic all the operations that are planned and performed taking into account an optimal aesthetic result regardless of the specific technique.

Results: There were 833 surgeries performed for 823 cancer patients. In 153 cases, patients had symmetrized procedures. The average weight of specimens was $112,9 \mathrm{~g}(2-1034 \mathrm{~g})$; the average size of tumors was $2,8 \mathrm{~cm}(0,2-15,8 \mathrm{~cm}) .106$ patients $(12,7 \%)$ had multifocal/multicentric tumors. In $(3,8 \%) 32$ cases involved margins were found and re-excision was required. $793(96,4 \%)$ patients were on follow up. The median follow-up period was 48 months (6-164 months). Local recurrence was found in $10(1,2 \%)$ patients, regional axillary recurrence - in $2(0,3 \%)$, systemic progression in $87(11,0 \%)$ patients and $50(6,2 \%)$ of them have died. Complications were observed in $190(23,1 \%)$ patients, mostly seromas and ischemic disorders.

Conclusions: We present our approaches to oncoplastic breast conserving surgery with focusing on the aesthetic results of the procedures. Oncological outcomes demonstrate the safety of advanced oncoplastic BCS in the framework of multidisciplinary teamwork.
\end{abstract}

Key words: oncoplastic breast surgery, therapeutic mammaplasty, regional perforant flaps, breast conserving surgery, volume replacement, volume displacement

\section{Introduction}

Breast cancer (BC) is still the leading cause of oncological morbidity and mortality among women in most countries worldwide (1). During the last decades, the treatment paradigm has changed significantly thanks to new knowledge about cancer biology, which allowed finding 
new mechanisms to affect tumors, and as a result, new drugs. This approach allows for the individualization of the treatment and significantly improves its results notably increasing the number of cancer survivors and their lifetime. Due to the important role of the breast in patients' self-image, the new approaches to BC treatment are also focused on patients' quality of life (QoL). The QoL concept, among other things, includes two basic parameters - functional and aesthetic $(2,3)$. Therefore, the requirements for modern breast surgery have changed a lot. Now, it should be not only radical but also as much functional (taking into account the convenience and the needs of a patient) and aesthetic as possible without compromising the oncological principles. These approaches were mainly realized in the concept of oncoplastic surgery, which was proposed by Audretsch in the early '90s (4). Now oncoplastic surgery has become the mainstream of breast surgery because it gives a patient both better aesthetic results and better oncological outcomes in terms of local recurrence and overall survivor (5-9). The optimal treatment of $\mathrm{BC}$ should be multimodal and take into the account as many features of the tumor and patient's needs as possible. This principle can be only realized with the multidisciplinary approach in a specialized Breast Unit organized according to EUSOMA criteria (10). We present our approach and experience in oncoplastic breast surgery in the first Breast Unit in Ukraine that was organized according to the EUSOMA criteria in 2010.

\section{Materials and Methods}

We have performed a retrospective review of patients who underwent breast conserving surgery at the Breast Unit of LISOD Hospital of Israeli Oncology focusing on the decisionmaking process of the surgery type selection, long-term results of treatment and number of complications. We consider as oncoplastic all the operations that are planned and performed taking into account the optimal aesthetic result, regardless of the specific surgical technique. All our patients have had initial triple assessment: clinical examination with anamnesis evaluation by a medical oncologist during the first visit, imaging staging according to NCCN recommendations (11) and tissue sampling by core needle biopsy with the histological and immunohistochemical investigation. The patients with triple-negative $\mathrm{BC}$, with family history and patients younger 45 y.o. had also been examined on BRCA $1 / 2$ genes mutations. After the complete initial examination, after surgical procedures or before changing the treatment plan, all the patients were discussed by a multidisciplinary tumor board (which meets twice a week) consisting of medical oncologists, radiation oncologists, oncoplastic breast surgeon, pathologist and breast radiologist. An individual plan of treatment was proposed and approved by consensus for each patient according to NCCN guidelines. If a patient needed the surgery, an additional consultation with a surgeon had been planned before the procedure. All kinds of techniques, including oncological and reconstructive stages, were performed by one surgeon - a trained oncoplastic surgeon, without a plastic surgeon. A patient was informed about different options of the procedures according to the tumor characteristics and the patient's anatomy. The final decision was made, taking into account the patient's preferences. In our practice, we prefer oncoplastic breast conservation. If a patient needed neoadjuvant treatment, the initial status and the size and position of a tumor was fixed by a surgeon before the treatment started, and an option of tumor tissue marking was discussed. After neoadjuvant therapy before the surgery all of the patients underwent MRI of the breast for residual tumor evaluation in order to make the final decision about the surgical technique. Closely before an operation, the photos of all the patients in standard positions and with presurgery markings in standing positions were made. In cases with complete clinical response, tumor site localization was performed on the day of surgery. The wire-guided localization or Radioguided Occult Lesion Localization (ROLL) were used. During the surgery, the color marking of the specimen was done by the 
surgeon, and the pathologist evaluated the margins of the specimen. In case of doubts or after neoadjuvant treatment, frozen sections of the margins were performed by the pathologist in the operation theatre. The final decision about the type of surgical technique was made only after confirmation of the margin`s free status. If therapeutic mammoplasty was planned, the immediate symmetrization procedure was recommended to the patient. If a patient refused immediate symmetrization, we tried to postpone it for one year following radiotherapy.

\section{Results}

All the consecutive cases of breast conserving surgery from 2007 to December 2020 per- $^{-}$ formed in a single institution in prospectively maintained databases were included in the review. 833 surgeries were performed for 823 patients for cancer during this period, 10 (1.2\%) patients had bilateral tumors. The average age of patients was $53(22-88)$ years. Demographic data of the patients and tumors characteristics are presented in Table 1. In our classification of oncoplastic procedures, we

Table 1. Demographic data of the patients and characteristics of the tumors

\begin{tabular}{|c|c|c|c|c|c|c|c|}
\hline \multicolumn{2}{|l|}{ Techniques } & $\begin{array}{l}\text { Level } 1 \\
\text { technique }\end{array}$ & $\begin{array}{l}\text { Advanced } \\
\text { parenchymal } \\
\text { displacement }\end{array}$ & $\begin{array}{l}\text { Therapeutic } \\
\text { mammoplasties }\end{array}$ & $\begin{array}{l}\text { Regional flaps } \\
\text { with wide base }\end{array}$ & $\begin{array}{l}\text { Regional island } \\
\text { perforant flaps }\end{array}$ & All \\
\hline \multicolumn{2}{|l|}{ No. of patients } & $203(24.7 \%)$ & $61(7.4 \%)$ & $388(47.1 \%)$ & $84(10.2 \%)$ & $87(10.6 \%)$ & 823 \\
\hline \multicolumn{2}{|c|}{ No. of operations } & $205(24.6 \%)$ & $61(7.3 \%)$ & $396(47.6 \%)$ & $84(10.1 \%)$ & $87(10.4 \%)$ & 833 \\
\hline \multicolumn{2}{|c|}{ Average age (range) } & $53(22-88)$ & $55(29-76)$ & $54(25-81)$ & $53(30-76)$ & $45(23-74)$ & $53(22-88)$ \\
\hline Laterality & $\begin{array}{l}\text { Left } \\
\text { Right } \\
\text { Bilateral }\end{array}$ & $\begin{array}{l}104(51.2 \%) \\
97(47.8 \%) \\
2(1 \%)\end{array}$ & $\begin{array}{l}26(42.6 \%) \\
35(57.4 \%) \\
0\end{array}$ & $\begin{array}{l}194(49.7 \%) \\
186(47.6 \%) \\
8(2.6 \%)\end{array}$ & $\begin{array}{l}36(42.8 \%) \\
48(57.2 \%) \\
0\end{array}$ & $\begin{array}{l}41(47.2 \%) \\
46(52.8 \%) \\
0\end{array}$ & $\begin{array}{l}401(48.7 \%) \\
412(50.1 \%) \\
10(1.2 \%)\end{array}$ \\
\hline Cup size: & $\begin{array}{l}A \\
B \\
C \\
D \\
E\end{array}$ & $\begin{array}{l}13(6.4 \%) \\
94(46.3 \%) \\
42(20.7 \%) \\
36(17.7 \%) \\
18(8.9 \%)\end{array}$ & $\begin{array}{l}2(3.3 \%) \\
10(16.4 \%) \\
28(45.9 \%) \\
15(24.6 \%) \\
6(9.8 \%)\end{array}$ & $\begin{array}{l}1(0.2 \%) \\
72(18.6 \%) \\
159(41 \%) \\
98(25.3 \%) \\
58(14.9 \%)\end{array}$ & $\begin{array}{l}3(3.6 \%) \\
26(31 \%) \\
30(35.7 \%) \\
18(21.4 \%) \\
7(8.3 \%)\end{array}$ & $\begin{array}{l}10(11.5 \%) \\
57(65.5 \%) \\
12(13.8 \%) \\
5(5.8 \%) \\
3(3.4 \%)\end{array}$ & $\begin{array}{l}29(3.5 \%) \\
259(31.5 \%) \\
271(32.9 \%) \\
172(20.9 \%) \\
92(11.2 \%)\end{array}$ \\
\hline $\begin{array}{l}\text { Location of } \\
\text { the tumor\#: }\end{array}$ & $\begin{array}{l}\text { Upper-outer } \\
\text { Lower-outer } \\
\text { Upper-inner } \\
\text { Lower-inner } \\
\text { Central }\end{array}$ & $\begin{array}{l}123(60.6 \%) \\
21(10.3 \%) \\
40(19.7 \%) \\
7(3.5 \%) \\
12(5.9 \%)\end{array}$ & $\begin{array}{l}42(68.9 \%) \\
4(6.6 \%) \\
6(9.8 \%) \\
3(4.9 \%) \\
6(9.8 \%)\end{array}$ & $\begin{array}{l}192(49.5 \%) \\
67(17.3 \%) \\
41(10.5 \%) \\
21(5.4 \%) \\
67(17.3 \%)\end{array}$ & $\begin{array}{l}74(88.1 \%) \\
10(11.9 \%) \\
0 \\
0 \\
0\end{array}$ & $\begin{array}{l}57(65.5 \%) \\
15(17.2 \%) \\
5(5.8 \%) \\
0 \\
10(11.5 \%)\end{array}$ & $\begin{array}{l}488(59.3 \%) \\
117(14.2 \%) \\
92(11.2 \%) \\
31(3.8 \%) \\
95(11.5 \%)\end{array}$ \\
\hline $\begin{array}{l}\mathrm{pT} \\
\text { (including DCIS } \\
\text { component) \% }\end{array}$ & $\begin{array}{l}\text { Tis } \\
0 \\
1 \mathrm{a} \\
1 \mathrm{~b} \\
1 \mathrm{c} \\
2 \\
3\end{array}$ & $\begin{array}{l}35(17.2 \%) \\
15(7.4 \%) \\
3(1.5 \%) \\
13(6.4 \%) \\
110(54.2 \%) \\
52(25.6 \%) \\
0\end{array}$ & $\begin{array}{l}14(23 \%) \\
4(6.6 \%) \\
1(1.6 \%) \\
3(4.9 \%) \\
20(32.8 \%) \\
29(47.5 \%) \\
3(4.9 \%) \\
\end{array}$ & $\begin{array}{l}69(17.8 \%) \\
7(1.8 \%) \\
3(0.8 \%) \\
12(3.1 \%) \\
89(22.3 \%) \\
223(57.5 \%) \\
26(6.7 \%) \\
\end{array}$ & $\begin{array}{l}13(15.5 \%) \\
5(6 \%) \\
0 \\
6(7.1 \%) \\
20(23.8 \%) \\
39(46.4 \%) \\
3(3.6 \%) \\
\end{array}$ & $\begin{array}{l}24(27.6 \%) \\
9(10.4 \%) \\
3(3.5 \%) \\
3(3.5 \%) \\
23(26.5 \%) \\
39(44.9 \%) \\
0\end{array}$ & $\begin{array}{l}155(18.8 \%) \\
40(4.9 \%) \\
10(1.2 \%) \\
37(4.5 \%) \\
262(31.8 \%) \\
382(46.4 \%) \\
32(3.9 \%) \\
\end{array}$ \\
\hline Status pN & $\begin{array}{l}\text { N0 } \\
\text { N1 } \\
\text { N2 } \\
\text { N3 }\end{array}$ & $\begin{array}{l}146(71.9 \%) \\
40(19.7 \%) \\
13(6.2 \%) \\
6(2.9 \%)\end{array}$ & $\begin{array}{l}47(77 \%) \\
12(19.7 \%) \\
3(4.9 \%) \\
13(21.3 \%)\end{array}$ & $\begin{array}{l}229(59 \%) \\
98(25.3 \%) \\
24(6.2 \%) \\
10(2.6 \%)\end{array}$ & $\begin{array}{l}48(57.1 \%) \\
21(25 \%) \\
9(10.7 \%) \\
6(7.1 \%)\end{array}$ & $\begin{array}{l}47(54.1 \%) \\
21(24.2 \%) \\
5(5.8 \%) \\
1(1.2 \%)\end{array}$ & $\begin{array}{l}517(62.8 \%) \\
192(23.3 \%) \\
54(6.6 \%) \\
36(4.4 \%) \\
\end{array}$ \\
\hline$\overline{\text { Stage }}$ & $\begin{array}{l}0 \\
1 \\
2 \mathrm{a} \\
2 \mathrm{~b} \\
3 \mathrm{a} \\
3 \mathrm{~b} \\
3 \mathrm{c}\end{array}$ & $\begin{array}{l}13(6.4 \%) \\
98(48.3 \%) \\
52(25.6 \%) \\
21(10.3 \%) \\
14(6.9 \%) \\
2(1 \%) \\
7(3.4 \%)\end{array}$ & $\begin{array}{l}2(3.2 \%) \\
17(27.8 \%) \\
17(27.8 \%) \\
13(21.3 \%) \\
3(4.9 \%) \\
3(4.9 \%) \\
4(6.6 \%)\end{array}$ & $\begin{array}{l}4(1 \%) \\
62(16 \%) \\
153(39.4 \%) \\
100(25.8 \%) \\
41(10.6 \%) \\
7(1.8 \%) \\
14(3.6 \%)\end{array}$ & $\begin{array}{l}1(1.2 \%) \\
16(19 \%) \\
32(38.1 \%) \\
16(19 \%) \\
11(13.1 \%) \\
1(1.2 \%) \\
7(8.3 \%)\end{array}$ & $\begin{array}{l}3(3.5 \%) \\
12(13.8 \%) \\
41(47.2 \%) \\
24(27.6 \%) \\
3(3.5 \%) \\
0 \\
1(1.2 \%)\end{array}$ & $\begin{array}{l}23(2.8 \%) \\
191(23.2 \%) \\
294(35.7 \%) \\
174(21.1 \%) \\
69(8.4 \%) \\
13(1.6 \%) \\
33(4 \%)\end{array}$ \\
\hline \multicolumn{2}{|c|}{$\begin{array}{l}\text { Multifocal/ } \\
\text { multicentric tumors }\end{array}$} & $7(3.4 \%)$ & $10(16.4 \%)$ & $69(17.4 \%)$ & $7(8.3 \%)$ & $13(14.9 \%)$ & $106(12.7 \%)$ \\
\hline \multicolumn{2}{|c|}{$\begin{array}{l}\text { Average weight of } \\
\text { specimen (min-max), g }\end{array}$} & $44.6(2-360)$ & $107.8(12-412)$ & $158.2(10-1034)$ & $101.5(5-550)$ & $54.8(10-150)$ & $112.9(2-1034)$ \\
\hline \multicolumn{2}{|c|}{$\begin{array}{l}\text { Average size of tumor } \\
\text { (min-max), cm * } \\
2.8(0.2-15.8)\end{array}$} & & $2.1(0.6-10)$ & $2.76(0.5-3.7)$ & $3.2(0.2-15.8)$ & $2.6(0.8-7.0)$ & $2.8(1.1-5.5)$ \\
\hline
\end{tabular}


Table 1. Demographic data of the patients and characteristics of the tumors (continuation)

\begin{tabular}{|c|c|c|c|c|c|c|c|}
\hline \multicolumn{2}{|l|}{ Techniques } & $\begin{array}{l}\text { Level } 1 \\
\text { technique }\end{array}$ & $\begin{array}{l}\text { Advanced } \\
\text { parenchymal } \\
\text { displacement }\end{array}$ & $\begin{array}{l}\text { Therapeutic } \\
\text { mammoplasties }\end{array}$ & $\begin{array}{l}\text { Regional flaps } \\
\text { with wide base }\end{array}$ & $\begin{array}{l}\text { Regional island } \\
\text { perforant flaps }\end{array}$ & All \\
\hline \multicolumn{2}{|l|}{ R1 resection } & $10(4.9 \%)$ & $4(6.6 \%)$ & $11(2.8 \%)$ & $4(4.8 \%)$ & $3(3.5 \%)$ & $32(3.8 \%)$ \\
\hline \multicolumn{2}{|c|}{ Symmetrized procedures } & 0 & 0 & $153(38.6 \%)$ & 0 & 0 & $153(18.4 \%)$ \\
\hline $\begin{array}{l}\text { Tumor localization } \\
\text { technique }\end{array}$ & $\begin{array}{l}\text { US } \\
\text { FNL } \\
\text { ROLL/SNOLL }\end{array}$ & $\begin{array}{l}19(9.3 \%) \\
31(15.2 \%) \\
11(5.4 \%) \\
\end{array}$ & $\begin{array}{l}4(6.6 \%) \\
5(8.2 \%) \\
2(3.3 \%) \\
\end{array}$ & $\begin{array}{l}18(4.6 \%) \\
68(17.2 \%) \\
7(1.8 \%) \\
\end{array}$ & $\begin{array}{l}4(4.8 \%) \\
11(13.1 \%) \\
3(3.6 \%) \\
\end{array}$ & $\begin{array}{l}2(2.3 \%) \\
16(18.4 \%) \\
1(1.2 \%) \\
\end{array}$ & $\begin{array}{l}47(5.6 \%) \\
144(17.3 \%) \\
24(2.9 \%)\end{array}$ \\
\hline \multicolumn{2}{|l|}{ SLNB } & $162(79 \%)$ & $45(73.7 \%)$ & $258(65.2 \%)$ & $60(71.4 \%)$ & $59(67.8 \%)$ & $584(70.1 \%)$ \\
\hline \multicolumn{2}{|l|}{$\overline{A L N D}$} & $59(28.3 \%)$ & $22(36 \%)$ & $165(41.7 \%)$ & $37(44 \%)$ & $36(41.4 \%)$ & $319(38.3 \%)$ \\
\hline \multirow[t]{3}{*}{$\begin{array}{l}\text { Histologic type } \\
\text { of tumor }\end{array}$} & $\begin{array}{l}\text { DCIS }^{\text {No }} \\
\text { Invasive ductal } \\
\text { carcinoma }\end{array}$ & $\begin{array}{l}18(8.8 \%) \\
161(79.3 \%)\end{array}$ & $\begin{array}{l}9(14.8 \%) \\
55(90.2 \%)\end{array}$ & $\begin{array}{l}8(2 \%) \\
298(76.8 \%)\end{array}$ & $\begin{array}{l}13(15.5 \%) \\
74(88.1 \%)\end{array}$ & $\begin{array}{l}24(27.6 \%) \\
71(81.7 \%)\end{array}$ & $\begin{array}{l}72(8.8 \%) \\
658(80 \%)\end{array}$ \\
\hline & $\begin{array}{l}\text { Invasive lobular } \\
\text { carcinoma }\end{array}$ & $19(9.3 \%)$ & $5(8.2 \%)$ & $35(9 \%)$ & $6(7.1 \%)$ & $4(4.8 \%)$ & $69(8.4 \%)$ \\
\hline & Other & $11(5.4 \%)$ & 0 & $12(3.1 \%)$ & $4(4.8 \%)$ & $4(4.8 \%)$ & $31(3.8 \%)$ \\
\hline Tumor Grade & $\begin{array}{l}1 \\
2 \\
3 \\
\end{array}$ & $\begin{array}{l}24(11.8 \%) \\
95(46.8 \%) \\
68(33.5 \%) \\
\end{array}$ & $\begin{array}{l}8(13.1 \%) \\
26(42.6 \%) \\
25(40.9 \%) \\
\end{array}$ & $\begin{array}{l}42(10.8 \%) \\
186(48 \%) \\
116(29.9 \%) \\
\end{array}$ & $\begin{array}{l}12(14.3 \%) \\
39(46.4 \%) \\
31(36.9 \%) \\
\end{array}$ & $\begin{array}{l}11(12.7 \%) \\
37(42.6 \%) \\
30(34.5 \%) \\
\end{array}$ & $\begin{array}{l}97(11.8 \%) \\
387(47 \%) \\
270(32.8 \%)\end{array}$ \\
\hline$\overline{\mathrm{DCIS}}$ grade & $\begin{array}{l}1 \\
2 \\
3 \\
\end{array}$ & $\begin{array}{l}3(1.5 \%) \\
14(6.9 \%) \\
13(6.4 \%) \\
\end{array}$ & $\begin{array}{l}1(1.6 \%) \\
2(3.3 \%) \\
6(9.8 \%) \\
\end{array}$ & $\begin{array}{l}4(1 \%) \\
36(9.3 \%) \\
17(4.4 \%) \\
\end{array}$ & $\begin{array}{l}1(1.2 \%) \\
4(4.8 \%) \\
9(10.7 \%) \\
\end{array}$ & $\begin{array}{l}4(4.8 \%) \\
8(9.2 \%) \\
11(12.7 \%) \\
\end{array}$ & $\begin{array}{l}13(1.6 \%) \\
64(7.8 \%) \\
56(6.8 \%)\end{array}$ \\
\hline \multicolumn{2}{|c|}{ Estrogen receptor positive } & $152(74.9 \%)$ & $40(65.6 \%)$ & $286(73.7 \%)$ & $67(79.8 \%)$ & $68(78.2 \%)$ & $613(74.5 \%)$ \\
\hline \multicolumn{2}{|c|}{ Progesterone receptor positive } & $135(66.5 \%)$ & $29(47.5 \%)$ & $248(63.9 \%)$ & $53(63.1 \%)$ & $57(65.6 \%)$ & $522(63.4 \%)$ \\
\hline HER-2neu status & $\begin{array}{l}\text { Positive } \\
\text { Negative }\end{array}$ & $\begin{array}{l}20(9.9 \%) \\
169(83.2 \%)\end{array}$ & $\begin{array}{l}12(19.7 \%) \\
49(80.3 \%)\end{array}$ & $\begin{array}{l}49(12.6 \%) \\
278(71.7 \%)\end{array}$ & $\begin{array}{l}13(15.5 \%) \\
68(80.1 \%)\end{array}$ & $\begin{array}{l}13(14.9 \%) \\
61(70.2 \%)\end{array}$ & $\begin{array}{l}107(13 \%) \\
625(75.9 \%)\end{array}$ \\
\hline \multicolumn{2}{|l|}{ Neodjuvant therapy } & $34(16.8 \%)$ & $13(21.3 \%)$ & $137(35.3 \%)$ & $17(20.2 \%)$ & $44(50.6 \%)$ & $245(29.8 \%)$ \\
\hline
\end{tabular}

divide volume displacement techniques into three subgroups: 1) level 1 techniques (simple local excision with wide mobilization of skin and parenchyma and tissue redistribution taking into account the location of surgical access and aesthetic results of the procedure; retroglandular "from inside" tumorectomy); 2) advanced parenchymal displacement (different types of rotations of parenchyma with the skin within breast; subdermal tumorectomy from contour access with advanced subdermal redistribution of the tissue); 3) level 2 techniques (therapeutic mammaplasties based on the principles of reduction mammaplasties and mastopexies). In volume replacement techniques we highlight two types: 1) regional flaps with wide skin base (lateral thoracic/axillary flaps, advanced rotational flap, thoracoepigastric flap) and 2) island perforant flaps (different types of LD flap, LTAP, LICAP, AICAP, MICAP flaps) (Fig. 1). We do not have experience in breast-sharing techniques and omental flap reconstruction. The data collection was performed considering the type of technique. The most used type of procedures was therapeutic mammaplasties - 395 (47.3\%) cases. Symmetrized procedures in this group were performed in 153 patients $(38.6 \%$ of patients with therapeutic mammaplasties and $18.4 \%$ of total number of patients with BCS). The group of island flaps techniques included patients with younger average age and smaller breasts sizes. Almost half of them $(50.6 \%)$ had neoadjuvant systemic treatment for tumor downstaging, which is obvious because of increased requirements for the aesthetic results in younger patients with small breasts. Multifocal/multicentric tumors were found in $106(12.7 \%)$ patients, mainly in advanced parenchymal rotations, therapeutic mammaplasties and island perforant flaps subgroups. These types of techniques allow restoring breasts with big defects. Involved 
Figure 1. The classification of oncoplastic breast conserving surgery techniques

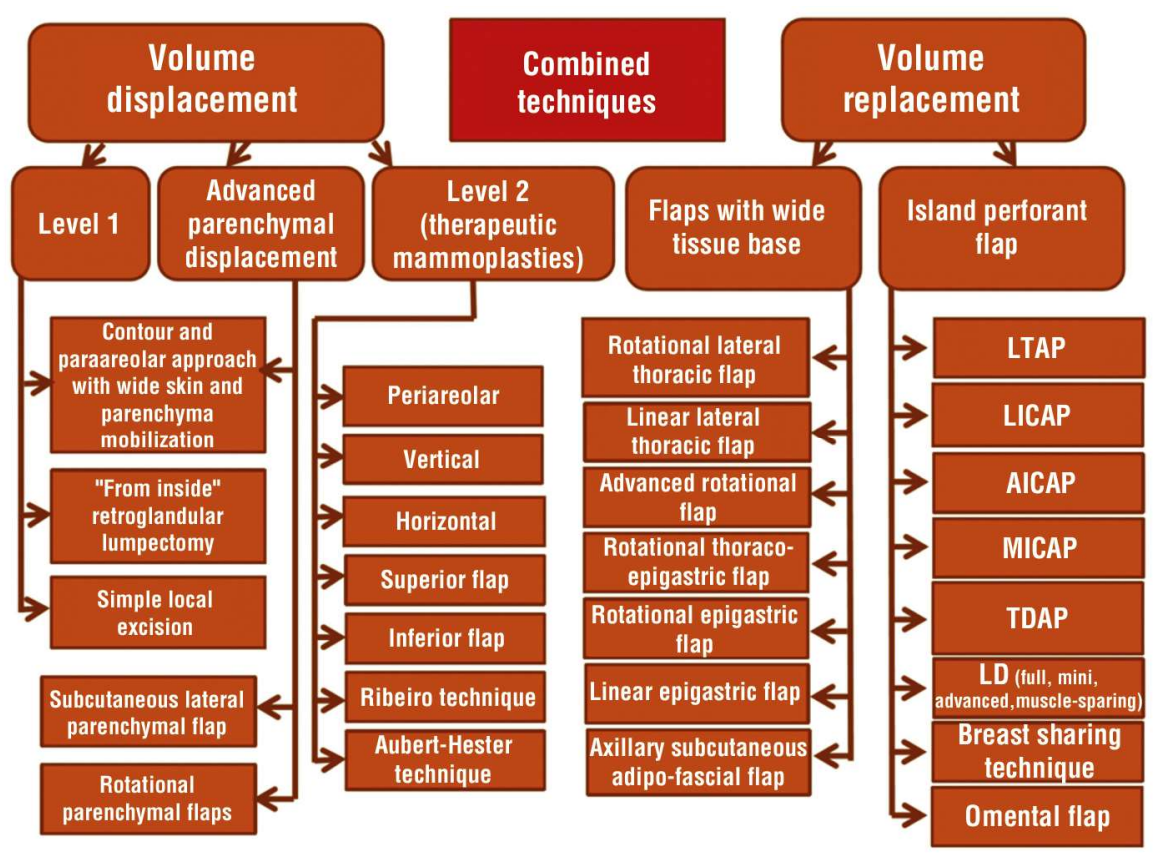

margins were found in $32(3.8 \%)$ patients. Two patients refused re-excisions; the others underwent re-lumpectomies with free margins or mastectomies with immediate reconstruction. Early complications were observed in 190 (23.1\%) cases, with revisions in $30(3.6 \%)$ cases (Table 2). The most frequent complications were seroma formation in $76(9.3 \%)$ cases and ischemic disorders in $57(6.8 \%)$ cases. The complications were most common in the group of regional flaps with wide base. 776 (92.3\%) patients were followed-up with an average period of $48(6-164)$ months. The oncological results of the treatment are presented in Table 3. We observed the local recurrence only in $10(1.2 \%)$ patients.

\section{Discussion}

Modern options of oncoplastic surgery usually offer various procedures to a patient: wide local excision (WLE), oncoplastic breast conservation, mastectomy and mastectomy with reconstruction. In the framework of adequate complex treatment all these surgical interventions usually provide a patient with the same

Table 2. Early complications rate

\begin{tabular}{|c|c|c|c|c|c|c|}
\hline Techniques: & $\begin{array}{l}\text { Level } 1 \\
\text { technique }\end{array}$ & $\begin{array}{l}\text { Advanced parenchymal } \\
\text { displacement }\end{array}$ & $\begin{array}{l}\text { Therapeutic } \\
\text { mammoplasties }\end{array}$ & $\begin{array}{l}\text { Regional flaps } \\
\text { with wide base }\end{array}$ & $\begin{array}{l}\text { Regional island } \\
\text { perforant flaps }\end{array}$ & All \\
\hline No. of surgeries & $205(24.6 \%)$ & $61(7.3 \%)$ & $396(47.6 \%)$ & $84(10.1 \%)$ & $87(10.4 \%)$ & 833 \\
\hline Seroma (wound / donor site) & $18(8.8 \%)$ & $8(12.8 \%)$ & $30(7.5 \%)$ & $11(13.2 \%)$ & $9(10.4 \%)$ & $76(9.1 \%)$ \\
\hline Hematoma & $3(1.5 \%)$ & $1(1.6 \%)$ & $10(2.6 \%)$ & $5(6 \%)$ & $4(4.8 \%)$ & $23(2.8 \%)$ \\
\hline Infection & $1(0.5 \%)$ & 0 & $10(2.6 \%)$ & $7(8.4 \%)$ & $1(1.2 \%)$ & $22(2.7 \%)$ \\
\hline Ischemia/necrosis of wound margins & $5(2.5 \%)$ & $2(3.2 \%)$ & $37(9.3 \%)$ & $4(4.9 \%)$ & $4(4.6 \%)$ & $50(6.1 \%)$ \\
\hline Complete flap necrosis & 0 & 0 & $5(1.3 \%)$ & 0 & $2(3.6 \%)$ & $7(0.9 \%)$ \\
\hline Spontaneous pneumothorax & 0 & 0 & $1(0.3 \%)$ & 0 & 0 & $1(0.1 \%)$ \\
\hline DVT & 0 & 0 & $1(0.3 \%)$ & 0 & 0 & $1(0.1 \%)$ \\
\hline PA embolism & 0 & 0 & $3(0.8 \%)$ & 0 & 0 & $3(0.3 \%)$ \\
\hline Other & $3(1.5 \%)$ & 0 & $3(0.8 \%)$ & $1(1.2 \%)$ & 0 & $7(0.8 \%)$ \\
\hline Total & $30(14.8 \%)$ & $11(18 \%)$ & $100(25.7 \%)$ & $28(33.3 \%)$ & $20(23 \%)$ & $190(23.1 \%)$ \\
\hline Revisions & $1(0.5 \%)$ & $1(1.6 \%)$ & $13(3.3 \%)$ & $10(12 \%)$ & $5(6 \%)$ & $30(3.6 \%)$ \\
\hline
\end{tabular}


Table 3. Oncological results

\begin{tabular}{lc}
\hline No. of patients & 823 \\
\hline Patients on follow-up, $\%$ & $793(96.4 \%)$ \\
\hline Median follow-up (min-max), months & $48(6-164)$ \\
\hline Local recurrence & $10(1.2 \%)$ \\
\hline Regional (axillary) recurrence & $2(0.3 \%)$ \\
\hline Systemic recurrence & $87(11.0 \%)$ \\
\hline Died due to progression & $50(6.2 \%)$ \\
\hline
\end{tabular}

systemic and local control. They do differ however by the functional and aesthetic results. That is why it is crucial to inform a patient adequately about different types of surgery which should take into account the features of the tumor and patients' needs. This approach of including the patient in the decision making process allows to choose the optimal technique. From our perspective, modern oncoplastic surgery should offer a patient not only the deformity prophylaxis but also the best possible and stable aesthetic result after an oncological operation. There is even some new terminology, e.g., "oncocosmetic" or "oncoaesthetic" surgery (12), which emphasizes the importance of aesthetic outcomes. Good surgery results may provide a patient compensation for stress from the disease. Thus, we are focusing on the aesthetic aspects of the surgery since oncological principles are clear and simple - a tumor should be removed completely with free margins. From our perspective, the aim of an oncoplastic operation is a complete restoration of breast appearance with minimal signs of the procedure or improving breast appearance with minimal scarring like in aesthetic surgery. There are many different techniques and modifications designed and used to achieve these purposes. The classification of oncoplastic breast conserving procedures includes volume displacement and volume replacement techniques. According to K.Clough classification, volume displacement techniques are divided into level 1 and level 2 (therapeutic mammaplasties) (13).

In level 1 techniques, the skin is spared maximally, and surgical access along the areola border or the submammary fold or the breast lateral border is usually used to hide the scar. The skin and parenchyma are mobilized widely to move them with effective defect closure without compromising the tissue's blood supply. It can be achieved by small local redistribution of tissue or by more wide parenchymal displacement (Fig. 2). This principle was described by Zhu et al (14). If a tumor is small and located close to the chest wall, we use retroglandular tumorectomy from contour access. The parenchyma is mobilized along the retromammary space, and lumpectomy is performed "from inside" (Fig. 3). The same approach was described by Matrai et al (15), but we use the modification of this technique - with cutting the deep layer of fascia, covering the posterior surface of the breast and partial cutting of parenchyma up to 3-5 $\mathrm{mm}$. It helps to release and redistribute the parenchyma with closing the defect more effectively. Our main principle in level 1 technique is "not to change the breast" after tumor removal. In our practice in volume displacement techniques, we highlight one more subgroup - advanced parenchymal displacement. This subgroup includes local parenchymal rotational flaps, advanced linear or rotational displacements of parenchyma with skin (Fig. A) or under the skin after wide mobilization. These techniques are more sophisticated than classical level 1 but do not meet the criteria of therapeutic mammaplasties. For instance, if the breast is small and a tumor is located medially, the lateral parenchymal flap can be used (Fig. 5). The lateral sector of parenchyma is mobilized widely from the skin along the mastectomy plain and from $\mathrm{m}$. pectoralis major along the retromammary space. Then, the tumor is removed with preservation of the lateral bridge-like part of the parenchyma - lateral parenchymal flap. To close the defect, this flap is moved medially. It is crucial to provide the adequate blood supply of this "bridge" of parenchyma. The same type of technique was proposed by T. Ogawa, et al (16). It is also possible to compensate the breast contour irregularity by axillary subcutaneous adipofascial tissue. Another important technical trick is closing the residual cavities. If a 
Figure 2. Level 1 technique from paraareolar access

(A) presurgical view with the tumor location and size;

(B) presurgical markings with "scenario B" - closing the defect by a rotational parenchymal flap in case of possible tumor bed extensive re-excision; (C) postsurgery view in 12 months after the surgery. after adjuvant radiotherapy in BED $50 \mathrm{Gr}$ in 25 fractions + boost on the tumor bed in $16 \mathrm{Gr}$ in 8 fractions. The weight of the specimen $14 \mathrm{~g}$
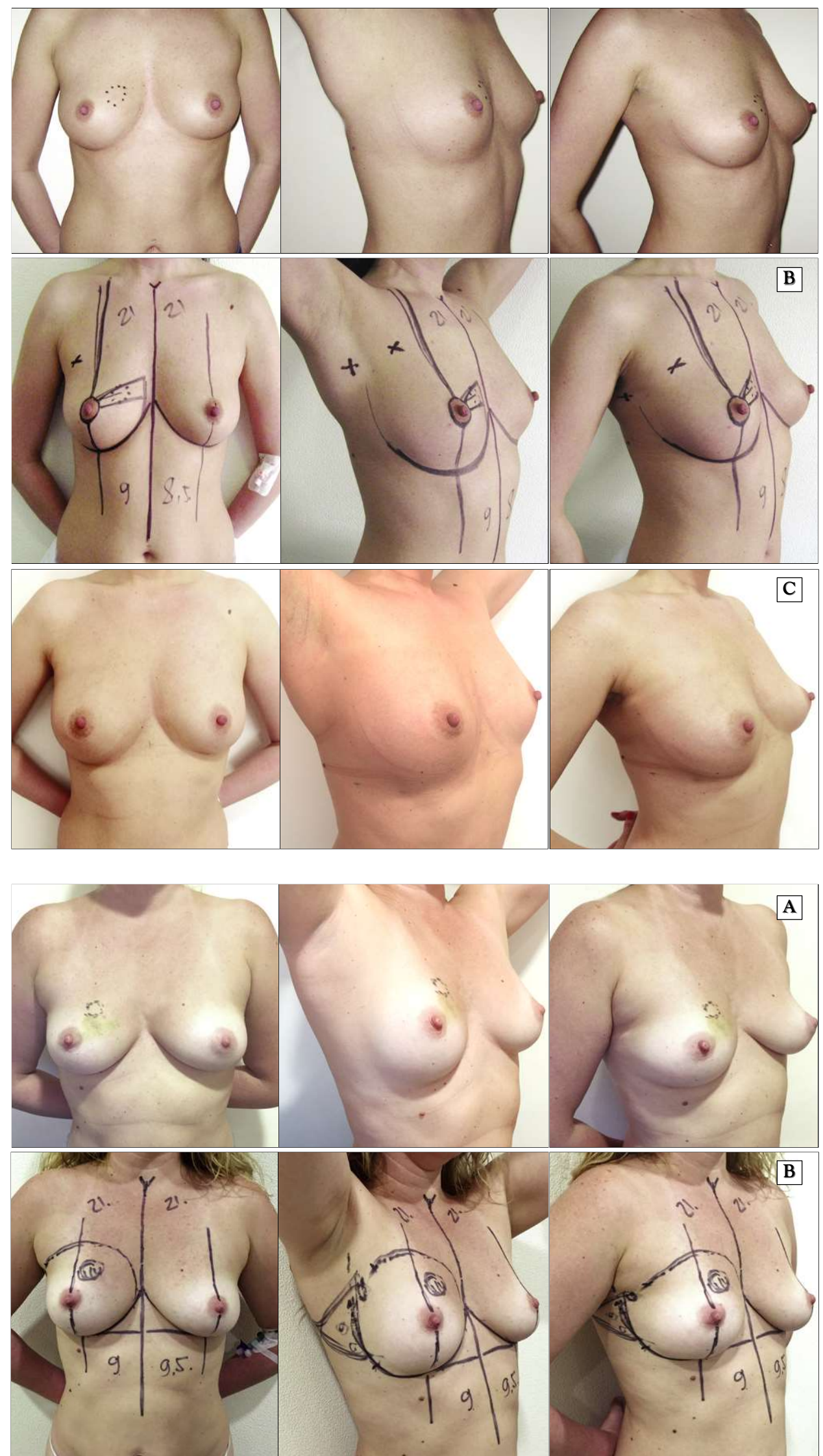

Figure 3. "From inside" technique from paraareolar access (A) presurgical view with the tumor location and size;

(B) presurgical markings with "scenario B" - closing the defect by LICAP flap in case of possible tumor bed re-excision 
Figure 3. "From inside" technique from paraareolar access

(C) postsurgery view in 24 months after the surgery. after adjuvant radiotherapy in BED 50 $\mathrm{Gr}$ in 25 fractions + boost on tumor bed in $16 \mathrm{Gr}$ in 8 fractions. The weight of the specimen $20 \mathrm{~g}$; (D) intraoperative photo with lateral contour access and the tumor bed; (E) partial closing of the defect with cutting the fascia and parenchyma around the defect; (F) final view on the table

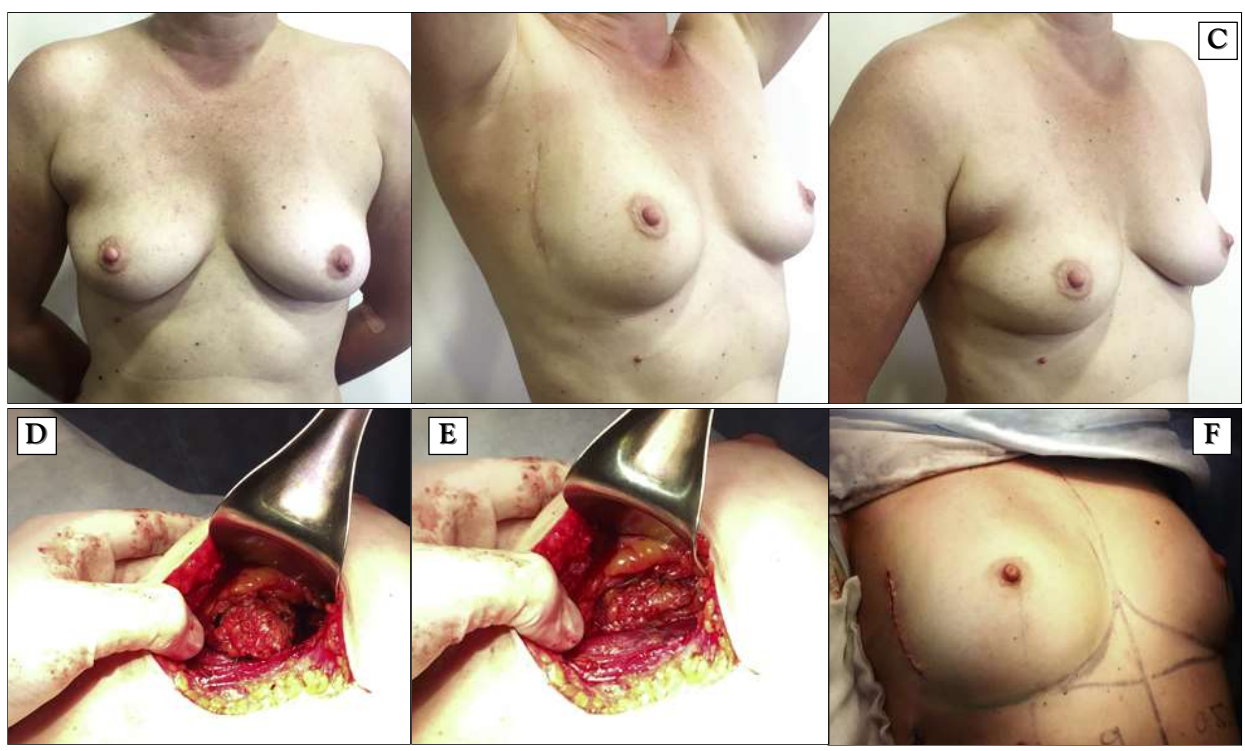

patient has big or ptotic breasts, the methods techniques of mammaplasty along with many of choice are level 2 techniques - therapeutic modifications. These types of oncoplastic mammaplasties. There are some basic surgery correspond with the principle "to

Figure 4. Advanced parenchymal displacement - rotational parenchymal flap

(A) presurgical view with the tumor location and size; (B) presurgical markings; (C) postsurgery view in 64 months after the surgery. after adjuvant radiotherapy in BED $50 \mathrm{Gr}$ in 25 fractions + boost on the tumor bed in $16 \mathrm{Gr}$ in 8 fractions. The weight of the specimen $70 \mathrm{~g}$

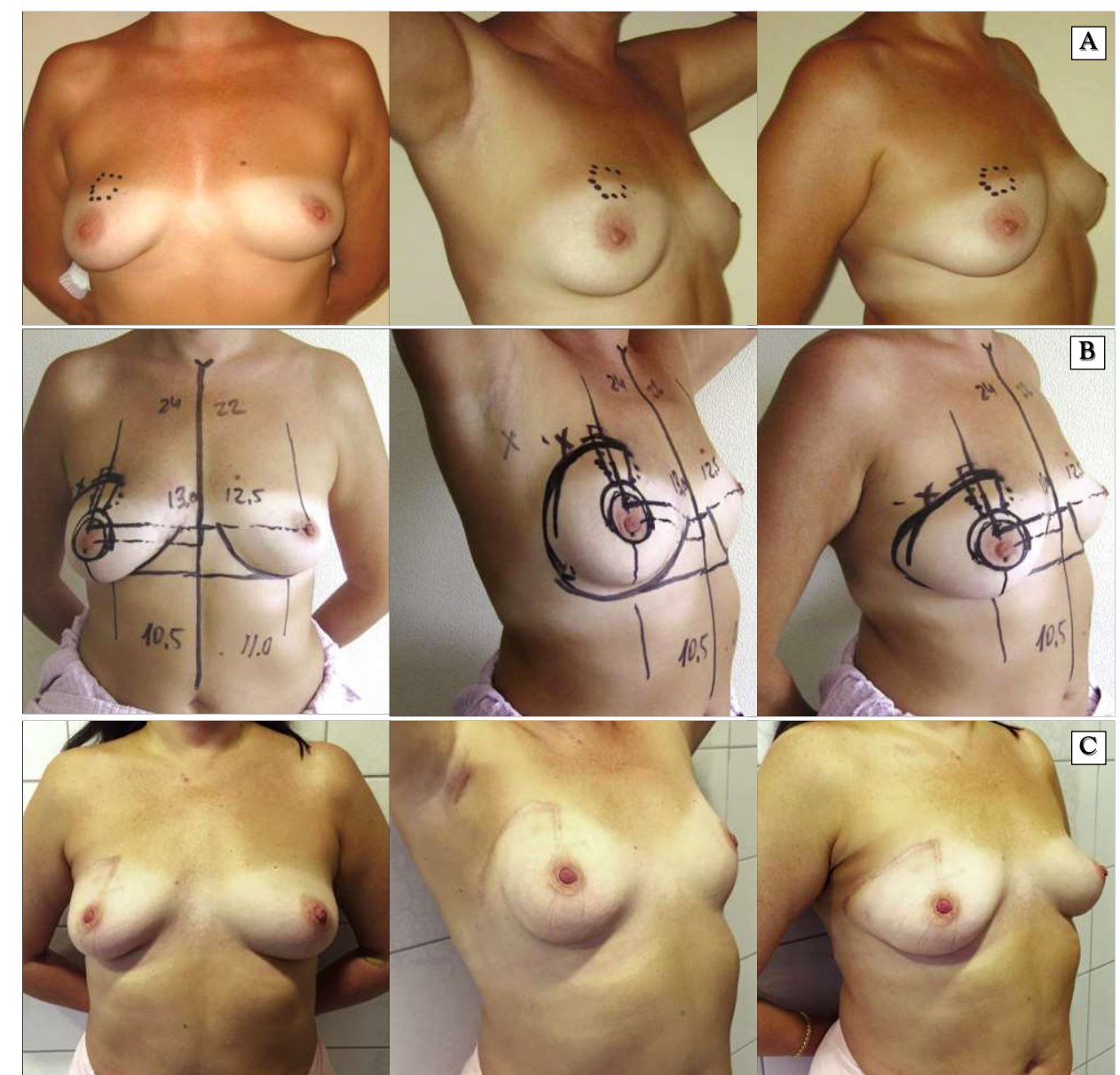


Figure 5. Lateral parenchymal flap technique from lateral contour access

(A) presurgical view with the tumor location and size; (B) presurgical markings with "scenario B" - closing the defect by LICAP flap in case of possible tumor bed re-excision; (C) postsurgery view in 8 months after the surgery. after adjuvant radiotherapy in BED $50 \mathrm{Gr}$ in 25 fractions + boost on the tumor bed in $16 \mathrm{Gr}$ in 8 fractions. The weight of the specimen $24 \mathrm{~g}$;

(D) intraoperative photo with lateral contour access. mobilized lateral part of parenchyma; the tumor was excised with preservation of lateral parenchymal bridge-like flap;

(E) lateral parenchymal flap is moved medially to close the defect; (F) final view on the table

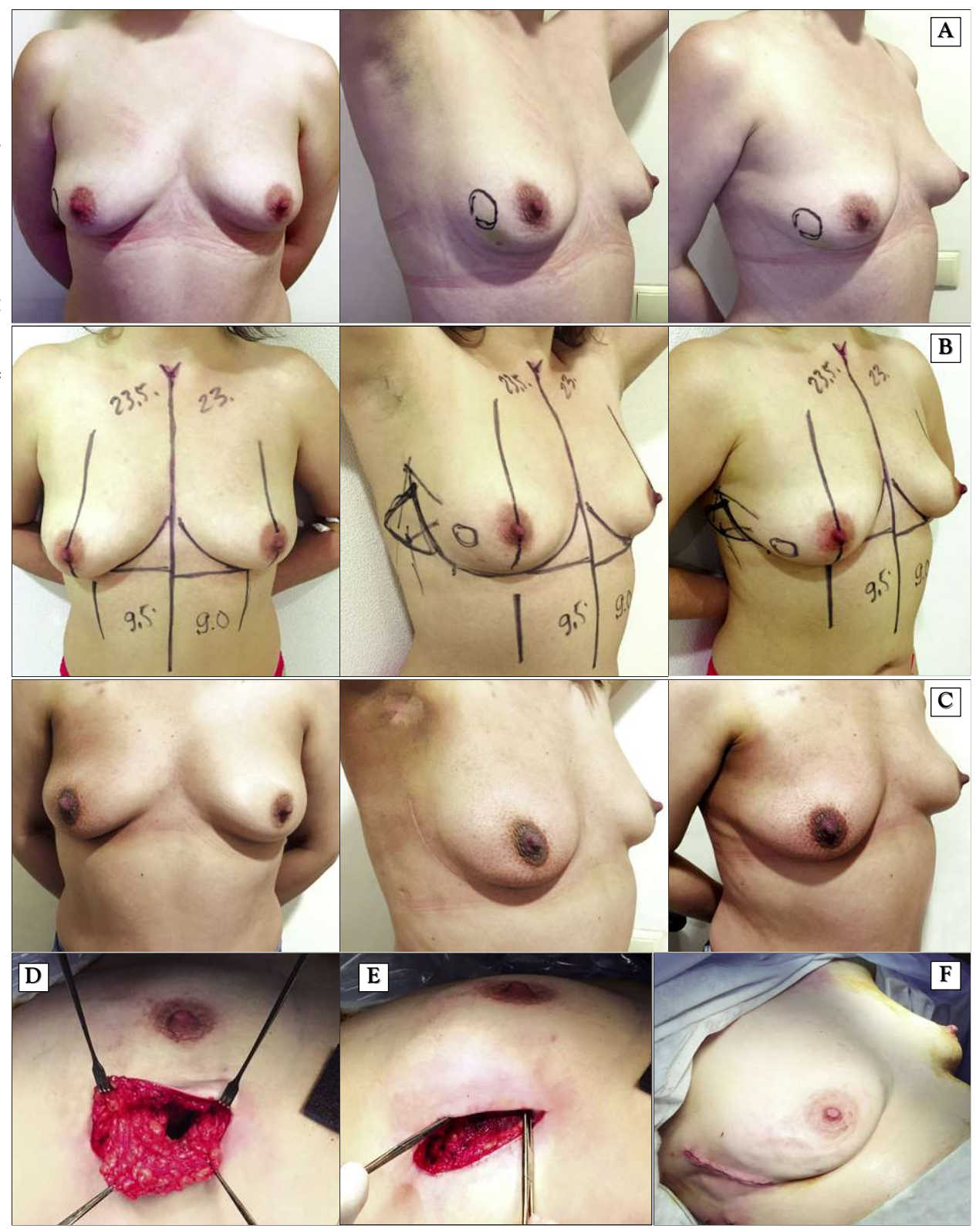

make the breasts better". We try to perform therapeutic mammaplasties similar to the aesthetic reduction mammaplasties with minimizing scarring. The most used procedures are the Wise pattern and modified Ribeiro procedure (17). In this type of techniques, the NAC remains on the upper part of the breast, while the lower part - the inferior flap - can be modified and moved in almost every part of the breast to close the defect after tumor removal (Fig. 6). In moderate breasts with ptosis, we use vertical or periareolar mammoplasty. The best aesthetic and functional results can be achieved with an immediate symmetrized procedure. Volume replacement techniques are used mostly in patients with small and moderate breasts when a tumor takes up a significant part of the breast volume (20-40\%) and sometimes when a patient wants to avoid asymmetry. The regional flaps can be performed with a wide tissue base (mostly with skin) (Fig. 7 ) or similar to the island perforant flaps. Different types of perforant flaps are well described in the literature and became more popular in oncoplastic breast surgery (18-21). In our 
Figure 6. Modified Ribeiro technique

(A) presurgical view with the tumor location and size; (B) presurgical markings with correction of the accessory mammary glands and brachioplasty; (C) postsurgery view in 33 months after the surgery. after adjuvant radiotherapy in BED $50 \mathrm{Gr}$ in 25 fractions + boost on the tumor bed in $16 \mathrm{Gr}$ in 8 fractions. The weight of the specimen $36 \mathrm{~g}$; (D) intraoperative photo with the tumor bed in superiormedial quadrant through Wise approach; (E) superior flap with NAC on the superior-lateral pedicle and inferior flap are prepared; (F) inferior flap is deepidermized. mobilized laterally and moved superiorly-medially to close the defect; (G) final view on the table

Figure 7. Lateral thoracic (axillary) flap with wide skin base

(A) presurgical view with the tumor location and size; (B) presurgical markings with flap position
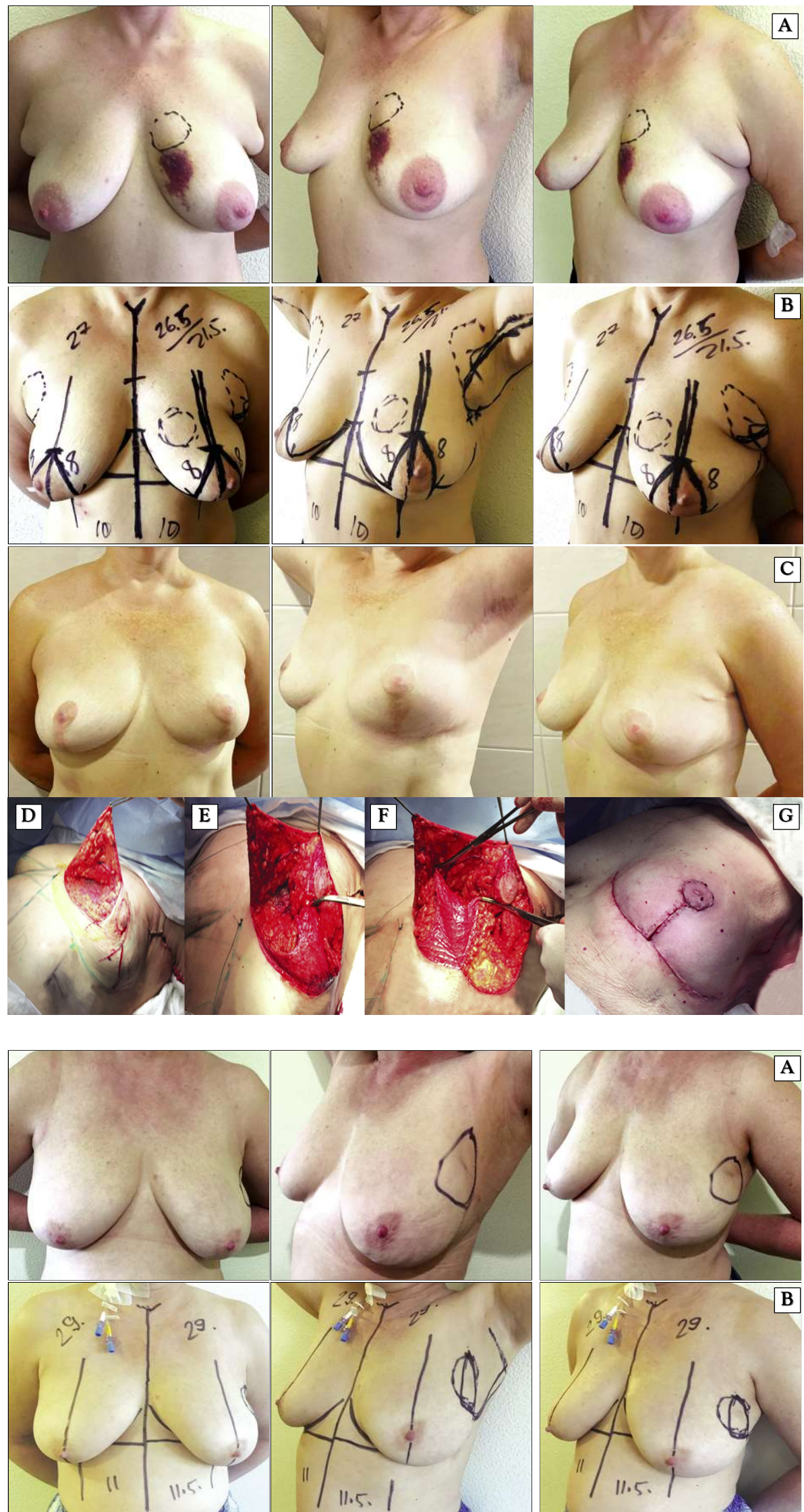
Figure 7. Lateral thoracic (axillary) flap with wide skin base

(C) postsurgery view in 3 months after the surgery. after adjuvant radiotherapy in BED $50 \mathrm{Gr}$ in 25 fractions + boost on the tumor bed in $16 \mathrm{Gr}$ in 8 fractions. The weight of the specimen $204 \mathrm{~g}$;

(D) intraoperative photo with the tumor bed and axillary flap; (E) vessels coming to the flap; (F) the flap is mobilized and moved anteriorly to close the defect

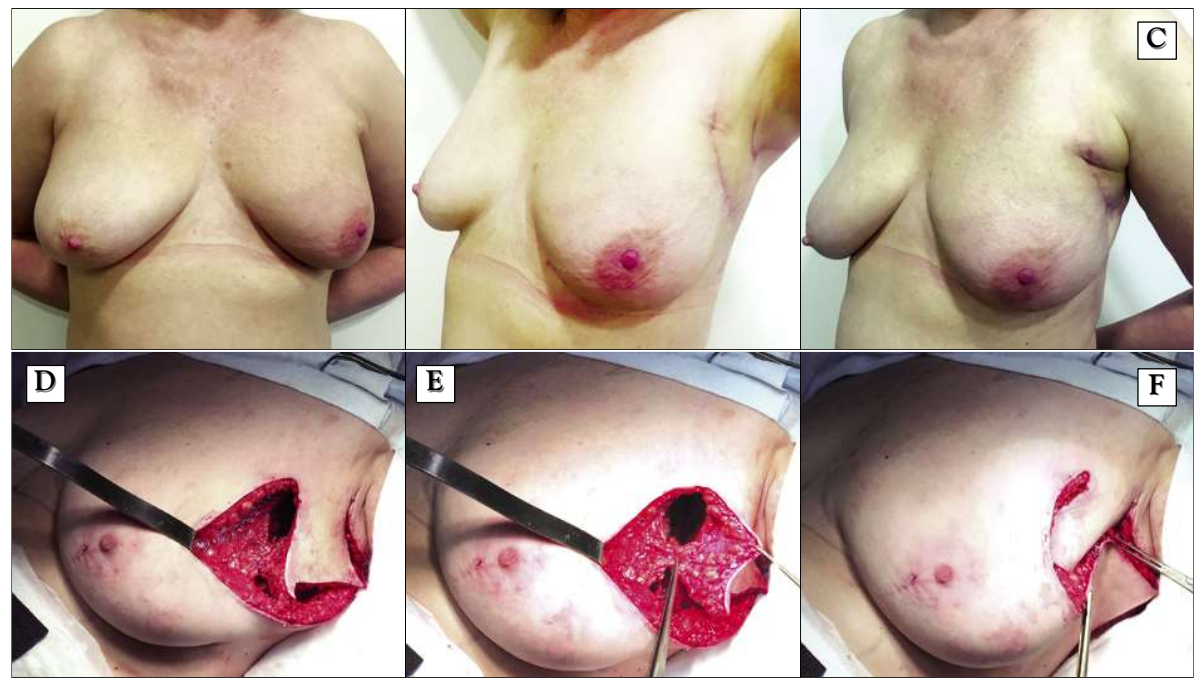

practice we try to minimize scars on the breast inferior mammary fold. It helps to restore the and correlate the borders of the flap with breast appearance completely with hidden natural borders of the breast - lateral and signs of intervention (Fig. 8). These types of

Figure 8. LICAP flap.

(A) presurgical view with the tumor location and size; (B) presurgical markings with fine needles localization of the borders of the tumor. flap position and other possible scenarios - closing the defect by AICAP flap and NAC sparing mastectomy in case of possible tumor bed re-excision;

(C) postsurgery view in 18 months after the surgery. after adjuvant radiotherapy in BED 50.4 Gr in 28 fractions. The weight of specimen $48 \mathrm{~g}$;

(D) intraoperative photo with surgical accesses along the lateral border of the breast and superior border of the areola. LICAP flap is mobilized and deepidermized; (E) the LICAP flap is being moved to the tumor bed;

(F) pre-final view on the table.

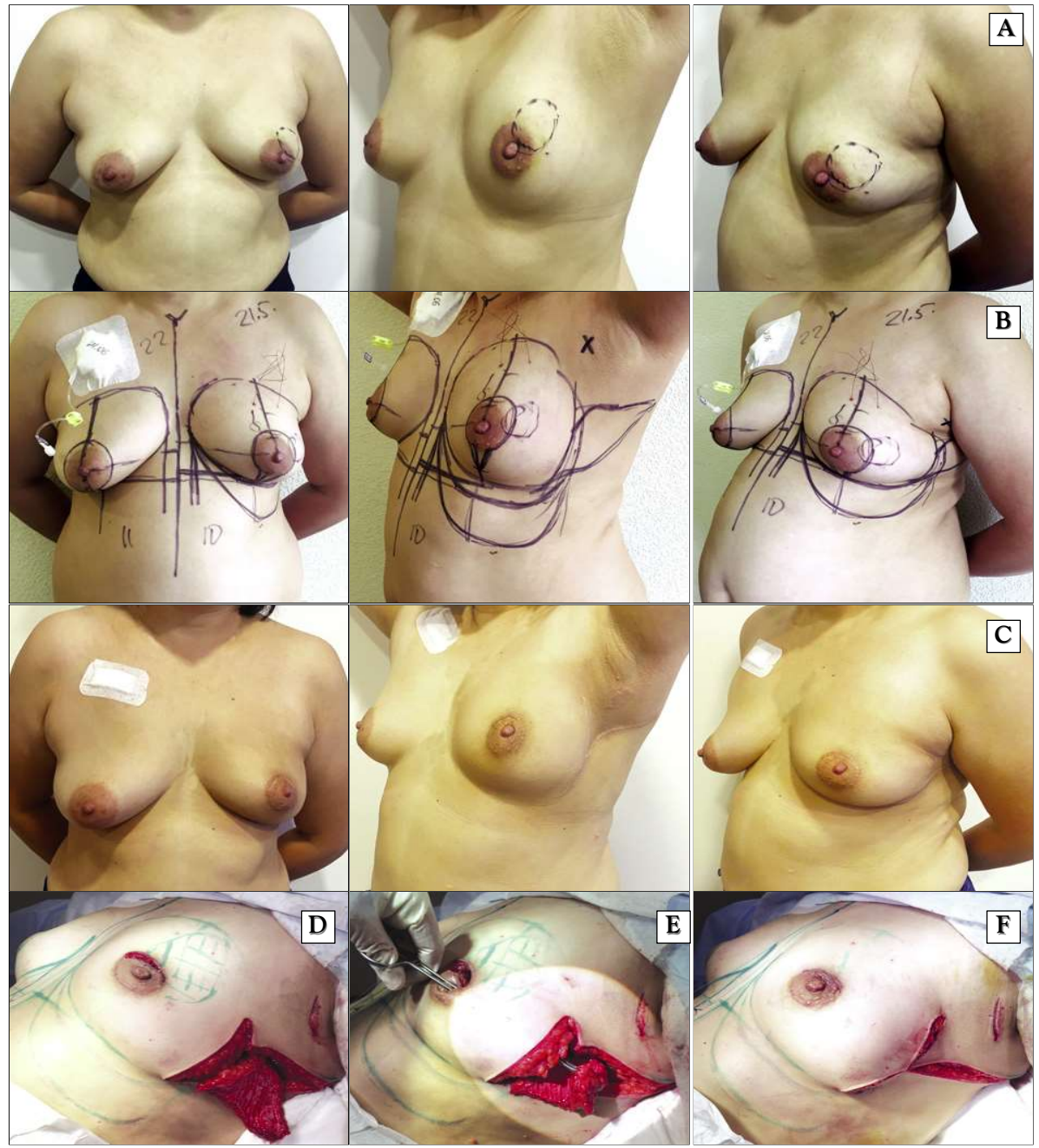


techniques are part of our concept of "invisible surgery" (22). While planning a surgery possible changes in a surgical plan should be considered, and the plan for possible changes of the procedure should be prepared and discussed with a patient. We call it the "scenario strategy". We divide the surgery into stages when a final specific scenario with a planned technique has to be chosen according to the margin status and the final defect size. The scenario which we use most often when discussing a plan is when the "from inside" technique may be advanced to LTAP/LICAP flap or even to NAC sparing mastectomy with immediate expander reconstruction. All these surgical options need real multidisciplinary teamwork and complete cooperation, especially between a surgeon, a radiologist and a pathologist in a perioperative period. The surgical decision depends on margin status during the surgery. Intraoperative frozen section is a reliable method of margin evaluation (23-25) which is very helpful in advanced oncoplastic surgery and allows to minimize the rate of $\mathrm{R} 1$ resections and re-excisions. While it requires more time and resources, it allowed as to achieve the rate of $\mathrm{R} 1$ resections is $3,8 \%$, which is quite acceptable according to the data from the literature (26-28). Otherwise, oncoplastic surgery is more sophisticated and requires special training from a surgeon, more resources and more time for the procedure. Obviously, the number of early surgical complications after oncoplastic procedures are higher than in those after WLE, but it does not compromise oncological treatment. Meanwhile, the patients' satisfaction is much higher as well $(6,26,28)$.

\section{Conclusions}

We presented our approaches to oncoplastic breast conserving surgery focusing on the aesthetic results of the procedures. The rate of surgical complications is acceptable and correlates to the data from the literature. The oncological outcomes demonstrate the safety of advanced oncoplastic BCS in the framework of multidisciplinary teamwork. We believe that the more techniques an oncoplastic surgeon can use, the more individualized and effective surgery type he or she can choose for every single patient.

\section{Financial Disclosure Statement}

All the authors declare that they have nothing to disclose and have no conflicts of interest.

\section{Ethical Considerations}

This is the retrospective analysis and evaluation of partial breast reconstruction surgical techniques after tumor removal during breast conserving surgery. All the patients have signed the preoperative informed consent. The article was approved by the ethical committee of the LISOD Hospital of Israeli Oncology, where all the surgeries were performed.

\section{References}

1. https://www.uicc.org/what-we-do/thematic-areas-work/breast-cancer

2. Mokhatri-Hesari $P$, Montazeri A. Health-related quality of life in breast cancer patients: review of reviews from 2008 to 2018. Health Qual Life Outcomes. 2020;18(1):338

3. $\mathrm{Ng} \mathrm{ET}$, Ang RZ, Tran BX, Ho CS, Zhang Z, Tan W, et al. Comparing quality of life in breast cancer patients who underwent mastectomy versus breastconserving surgery: a meta-analysis. Int J Environ Res Public Health. 2019;16(24):4970.

4. Audretsch W, Rezai M, Kolotas C, et al. Onco-plastic surgery: "Target" volume reduction (BCT-mastopexy), lumpectomy, reconstruction (BCTreconstruction), and flap-supported operability in breast cancer. Second European Congress on Senology, Breast Diseases 1994:139-57.

5. Agarwal S, Pappas L, Neumayer L, Kokeny K, Agarwal J. Effect of breast conservation therapy vs mastectomy on disease-specific survival for earlystage breast cancer. JAMA Surg. 2014;149(3): 267-274.

6. Losken A, Dugal CS, Styblo TM, Carlson GW, A meta-analysis comparing breast conservation therapy alone to the oncoplastic technique. Ann. Plast. Surg. 2014;72(2):145-149

7. Chakravorty A, Shrestha AK, Sanmugalingam N, Rapisarda F, Roche N Querci Della Rovere G, et al. How safe is oncoplastic breast conservation? Comparative analysis with standard breast conserving surgery. Eur J Surg Oncol. 2012;38(5):395-8.

8. Chen JY, Huang YJ, Zhang LL, Yang CQ, Wang K. Comparison of Oncoplastic Breast-Conserving Surgery and Breast-Conserving Surgery Alone: A MetaAnalysis. J Breast Cancer. 2018:21(3):321-329.

9. Kosasih S, Tayeh S, Mokbel K, Kasem A. Is oncoplastic breast conserving surgery oncologically safe? A meta-analysis of 18,103 patients. Am J Surg. 2020;220(2):385-392

10. Biganzoli L, Cardoso F, Beishon M, Cameron D, Cataliotti L, Coles CE, et al. The requirements of a specialist breast centre. Breast. 2020:51:65-84.

11. NCCN guidelines (http://www.nccn.org/professionals/physician_gls/ $\mathrm{pdf} /$ breast.pdf).

12. Carmichael AR, Mokbel K. Evolving trends in breast surgery: oncoplastic to onco-aesthetic surgery. Arch Plast Surg 2016;43: 222-223.

13. Clough KB, Kaufman GJ, Nos C, Buccimazza I, M. Sarfati IM. Improving 
breast cancer surgery: a classification and quadrant per quadrant atlas for oncoplastic surgery. Ann Surg Oncol 2010; 17:1375-91.

14. Zhu L, Li S, Tan L, Zhang X, Wu J, Su F, et al. In pursuit of a flawless aphrodite: paving the way to scarless oncoplastic breast surgery. Cancer Commun (Lond). 2019;39(1):82.

15. Mátrai Z, Újhelyi M, Kovács T, Kelemen P, Sávolt A, Kovács E, et al Evaluation of a retroglandular oncoplastic technique as a standard level oncoplastic breast-conserving surgery: a retrospective clinicopathologic study of 102 patients with breast cancer. Clin Breast Cancer. 2019;19(3): e459-e467.

16. Ogawa T, Hanamura N, Yamashita M, Kimura H, Ito M, Nakamura T, et al Oncoplastic technique combining an adipofascial flap with an extended glandular flap for the breast-conserving reconstruction of small dense breasts. J Breast Cancer. 2012;15(4):468-473

17. Ribeiro L. A new technique for reduction mammaplasty. Plast Reconstr Surg 1975;55(3):330-4.

18. Hamdi M, Van Landuyt K, de Frene B, Roche N, Blondeel Ph, Monstrey S The versatility of the inter-costal artery perforator (ICAP) flaps. J Plast Reconstr Aesthet Surg. 2006;59(6):644-52.

19. Hamdi M, Spano A, Van Landuyt K, D'Herde K, Blondeel P, Monstrey S The lateral intercostal artery perforators: anatomical study and clinical application in breast surgery. Plast Reconstr Surg. 2008;121(2):389-396.

20. Hamdi M. Oncoplastic and reconstructive surgery of the breast. Breast. 2013;22 (Suppl 2):S100-5

21. McCulley SJ, Schaverien MV, Tan VKM, Macmillan RD. Lateral thoracic artery perforator (LTAP) flap in partial breast reconstruction. J Plast
Reconstr Aesthet Surg. 2015;68(5):686-91.

22. Zhygulin A, Palytsia V, Vinnytska D, Nedielchev V. Invisible surgery - concept of oncoplastic breast conserving surgery for selected patients. Eur J Surg Oncol. 2019:45(25):158

23. Butler-Henderson K, Lee AH, Price Rl, Waring K. Intraoperative assessment of margins in breast conserving therapy: a systematic review. Breast. 2014; 23(2):112-9.

24. Volders JH, Haloua MH, Krekel NMA, Negenborn VL, Barb E, Sietses C, et al. Neoadjuvant chemotherapy in breast-conserving surgery - consequences on margin status and excision volumes: a nationwide pathology study. Eur J Surg Oncol. 2016;42(7):986-93.

25. Tan MP, Sitoh NY, Sim AS. The value of intraoperative frozen section analysis for margin status in breast conservation surgery in a nontertiary institution. Int J Breast Cancer. 2014;2014:715404.

26. O'Connell RL, Baker E, Trickey A, Rattay T, Whisker L, Macmillan RD, et al. Current practice and short-term outcomes of therapeutic mammaplasty in the international TeaM multicentre prospective cohort study. Br J Surg. 2018;105(13):1778-1792.

27. Carter SA, Lyons GR, Kuerer HM, Bassett RL Jr, Oates S, Thompson A, et al. Operative and Oncologic Outcomes in 9861 Patients with Operable Breast Cancer: Single-Institution Analysis of Breast Conservation with Oncoplastic Reconstruction. Ann Surg Oncol. 2016;23(10):3190-8.

28. De La Cruz L, Blankenship SA, Chatterjee A, Geha R, Nocera N, Czerniecki BJ, et al. Outcomes After Oncoplastic Breast-Conserving Surgery in Breast Cancer Patients: A Systematic Literature Review. Ann Surg Oncol. 2016; 23(10):3247-58. 